\title{
Kemampuan Pemahaman Konsep dan Komunikasi Matematis: Pengaruh Model Pembelajaran Children Learning in Science (CLIS) Berbantuan Alat Peraga Edukatif
}

\author{
Taat Herliana ${ }^{1}$, Nanang Supriadi ${ }^{2}$, Rany Widyastuti ${ }^{3}$ \\ 1, 2 Prodi Pendidikan Matematika, Fakultas Tarbiyah dan Keguruan, Universitas Islam Negeri Raden Intan Lampung, Jl. \\ Letnan Kolonel H, Kota Bandar Lampung, Lampung \\ ${ }^{3}$ Prodi Pendidikan Matematika, IAIN Madura, Jl. Panglegur Km 4, Pamekasan, Jawa Timur, Indonesia \\ taatherlliana11@gmail.com
}

\begin{abstract}
The research aims to determine the ability to understand concepts and mathematical communication skills of high school students in Pesawaran after being given the Children Learning in Science (CLIS) learning treatment with the help of educational aids. This research method uses a quasy experimental design method. The research subjects consisted of 152 class XI students of SMAN 1 Negerikaton with 60 students as the research sample. The data analysis technique used the normality test, the homogeneity test with the statistical hypothesis test using the OneWay Multivariate Analysis of Variance (MANOVA) test. From the data obtained, the value of sig $0,00>0,05$ shows the average value that there is an influence of the CLIS learning model assisted by educational aids on the ability to understand concepts and mathematical communication skills compared to conventional learning models applied by educators in schools. The conclusion is that there are positive results for the learning model.

Keywords: CLIS, educational props, concept understanding ability, mathematical communication skills
\end{abstract}

Abstrak
Penelitian ini bertujuan untuk mengetahui kemampuan pemahaman konsep dan kemampuan komunikasi matematis peserta didik SMA di Pesawaran setelah diberi perlakuan pembelajaran Children Learning in Science (CLIS) berbantuan alat peraga edukatif. Metode penelitian ini menggunakan metode quasy experimental design. Subjek penelitian terdiri dari 152 peserta didik kelas XI SMAN 1 Negerikaton dengan 60 peserta didik sebagai sampel penelitian. Teknik analisis data menggunakan uji normalitas, uji homogenitas dengan uji hipotesis statistik yaitu menggunakan uji One-Way Multivariate Analysis of Variance (MANOVA). Dari data yang diperoleh nilai sig $0,00<0,05$ maka menunjukan nilai rata-rata bahwa terdapat pengaruh model pembelajaran CLIS berbantuan alat peraga edukatif terhadap kemampuan pemahaman konsep dan kemampuan komunikasi matematis dibandingkan model pembelajaran konvensional yang diterapkan oleh pendidik disekolah. Kesimpulannya adalah terdapat hasil yang positif terhadap model pembelajaran tersebut.

Kata kunci: CLIS, alat peraga edukatif, kemampuan pemahaman konsep, kemampuan komunikasi matematis

Copyright (c) 2021 Taat Herliana, Nanang Supriadi, Rany Widyastuti

$\triangle$ Corresponding author: Taat Herliana

Email Address: taatherlliana11@gmail.com (Jl. Letnan Kolonel H, Kota Bandar Lampung, Lampung)

Received 26 July 2021, Accepted 21 September 2021, Published 25 September 2021

\section{PENDAHULUAN}

Banyak dampak dari rendahnya minat belajar peserta didik, diantaranya seperti rendahnya kemampuan pemahaman konsep dan kemampuan komunikasi matematis. Hal tersebut relevan dengan penelitian yang dilakukan oleh Irgi dkk bahwa "tujuan pembelajaran matematika belum dapat tercapai sepenuhnya hal ini dibuktikan dari hasil observasi yang menunjukan bahwa kemampuan pemahman konsep dan kemampuan komunikasi matematis peserta didik masih rendah setelah dilakukan tes untuk melihat kemampuan dasar peserta didik" (Silaen, Adriana, and Rahayu 2021).

Pemahaman konsep merupakan salah satu yang menjadi perhatian cukup besar dalam bidang matematika, hal ini disebabkan karena mata pelajaran matematika menekankan pada sebuah konsep. 
Pemahaman konsep matematika artinya mengerti benar tentang konsep matematika, yaitu peserta didik dapat menerjemahkan, menafsirkan, dan menyimpulkan suatu konsep matematika berdasarkan pembentukan pengetahuannya sendiri, bukan sekedar menghafal (Jannah, Supriadi, and Suri 2019). Adapun indikator dari pemahaman konsep matematika diantaranya yaitu agar peserta didik dapat menyatakan ulang sebuah konsep, mengklasifikasi objek-objek menurut sifat-sifat tertentu (sesuai dengan konsepnya), menjelaskan dan menginterpretasikan hasil jawaban, memberikan contoh dan bukan contoh dari sebuah konsep, menyajikan konsep dalam berbagai bentuk representasi matematis, dan mengaplikasikan konsep atau algoritma dalam pemecahan masalah (Yulianah, Ni'mah, and Rahayu 2020).

Tidak hanya pemahaman, komunikasi juga merupakan kemampuan yang harus dimiliki oleh peserta didik, karena dengan komunikasi ide dapat didiskusikan, diperbaiki dan dikembangkan, selain itu dengan adanya kemampuan komunikasi matematis peserta didik dapat mengatur dan memperkuat gagasan matematisnya yang akan dituangkan secara lisan maupun tulisan pada saat proses pembelajaran (Fahrullisa, Putra, and Supriadi 2018). Komunikasi matematik merupakan: a) kekuatan sentral bagi peserta didik dalam merumuskan konsep dan strategi matematik, b) modal keberhasilan bagi peserta didik terhadap pendekatan dan penyelesaian dalam eksplorasi dan investigasi matematik, c) wadah bagi peserta didik dalam berkomunikasi dengan temannya untuk memperoleh informasi, membagi pikiran dan penemuan, curah pendapat, menilai dan mempertajam ide untuk meyakinkan orang lain.(Aminah, Wijaya, and Yuspriyati 2018). Indikator standar proses komunikasi yang direkomendasikan NCTM meliputi a) mengatur dan menggabungkan ide matematis peserta didik melalui komunikasi, b) mengkomunikasikan ide matematis peserta didik secara koheren dan jelas kepada peserta didik lain, guru, maupun dengan yang lainnya, 3) menganalisis dan mengevaluasi ide dan strategi matematis orang lain, 4) menggunakan bahasa matematika untuk menyatakan ide matematis dengan tepat (Andini et al. 2018)

Kemampuan pemahaman konsep dan kemampuan komunikasi matematis marupakan dua kemampuan yang perlu dikuasi oleh peserta didik. Hal ini selaras dengan maksud pembelajaran matematika yang tercantum dalam KTSP 2006 dan pada kurikulum 2013 (Sugandi and Benard 2018). Untuk meningkatkan kemampuan pemahaman konsep dan kemampuan komunikasi matematis peserta didik, dibutuhkan model pembelajaran yang efektif yang dapat meningkatkan pemahaman konsep dan komunikasi matematis peserta didik. Salah satu model pembelajaran yang dapat digunakan adalah model pembelajaran Children Learning in Science (CLIS). Model pembelajaran CLIS merupakan model pembelajaran yang berusaha mengembangkan gagasan atau ide peserta didik tentang suatu masalah tertentu dalam pembelajaran serta merekontruksi gagasan atau ide berdasarkan hasil percobaan dan pengamatan (Rositayani and Abadi 2019). Model ini dikembangkan oleh Driver di inggris tahun 1998. Model pembelajaran CLIS mempunyai tujuan agar pembelajaran dapat bertahan lama karena pembelajaran CLIS memuat tahap-tahap kegiatan peserta didik dalam mempelajari konsep yang diajarkan. Adapun tahapan-tahapan model pembelajaran CLIS, yaitu 1) Orientation (orientasi); 2) 
Elicitation of ideas (pemunculan gagasan); 3) Restructuring of ideas (penyusunan ulang gagasan); 4) Application of ideas (penerapan gagasan); 5) Review change in ideas (mengkaji ulang perubahan gagasan) (Krismayoni and Suarni 2020). Menurut Aminah menyatakan bahwa kelebihan model pembelajaran CLIS yaitu 1) membiasakan peserta didik belajar mandiri dalam memecahkan suatu masalah, 2) menciptakan kretivitas peserta didik untuk belajar sehingga tercipta suasana kelas yang lebih nyaman, terjalinnya kerjasama antar peserta didik terlibat secara langsung dalam kegiatan, 3) menciptkan lebih bermakna, 4) pendidik dalam mengajar akan lebih mudah, karena dapat menciptakan suasana belajar yang lebih aktif, 5) pendidik dapat menciptkan alat-alat atau media pembelajaran yang sederhana yang dapat ditemukan di kehidupan sehari-hari (Khansa, Pramudya, and Kuswardi 2018).

Peneliti juga bermaksud mengkombinasikan model tersebut dengan media pembelajaran. Penalaran dan koneksi matematis penting untuk diketahui pada saat peserta didik mengerjakan soal matematika. Media sebagai penunjang pembelajaran berfungsi sebagai jembataan penghubung untuk mengembangkan keterampilan berpikir pada mata pelajaran yang syarat dengan konten-konten abstrak (Putri and Basir 2020). Media merupakan segala sesuatu yang dapat merangsang perasaan, pikiran, perhatian serta kemampuan peserta didik sehingga dapat mendorong terjadinya suatu proses belajar pada peserta didik, salah satu media pembelajaran yang dapat membantu pendidik dan peserta didik dalam mencapai tujuan pembalajaran disebut alat peraga. Alat peraga adalah Peranan alat peraga harus dilakukan dengan tepat, demikian juga pemilihan jenisnya harus relevan dengan materi pendidikan yang akan dibahas, sehingga alat peraga berperan besar dalam kesuksesan sebuah proses pembelajaran.

Banyak penelitian mengenai penerapan model pembelajaran CLIS yang dipadukan dengan media pembelajaran berupa media Kit IPA dan teknik lainnya, salah satunya dilakukan oleh Novi (Suryani, Sakti, and Purwanto 2018); (Arisantiani, Putra, and Ganing 2017); (Rositayani and Abadi 2019), namun belum ada penelitian yang menggabungkan model pembelajaran CLIS dengan alat peraga PUTURAL (Putaran Turunan Aljabar). Putaran turunan aljabar merupakan alat peraga edukatif yang dikembangkan dengan memodifikasi permainan spin pada umumnya. Alat peraga edukatif ini dibuat dengan tujuan agar kemampuan pemahaman konsep dan kemampuan komunikasi matematis peserta didik dapat meningkat melalui aktivitas bermain alat peraga tersebut. Alat peraga putaran turunan aljabar memberikan pembelajaran yang menyenangkan namun bermakna. Dalam penelitian ini, akan ada tiga bagian lingkaran. Lingkaran terbesar merupakan pangkat variabel $x$, lingkaran sedang merupakan koefisien variabel $x$, dan lingkaran terkecil merupakan hasil dari turunan.

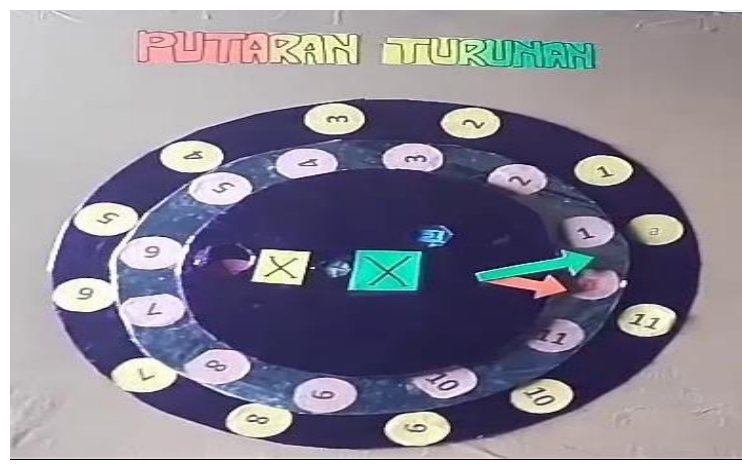




\section{Gambar 1. Alat Peraga Edukatif PUTURAL}

Alat peraga ini cukup menarik karena teknik memutar seperti ini mirip dengan permainan spin, sehingga menarik minat belajar peserta didik dan antusias dalam peoses belajar mengajar. Banyak penelitian serupa yang menggunakan alat peraga edukatif salah satunya yaitu penelitian ynag di lakukan oleh Een (Unaenah et al. 2020); (Nomleni and Manu 2018); dan (Irawan 2016), namun belum ada satu penelitian pun yang secara khusus menggunakan alat peraga edukatif putaran turunan aljabar yang dipadukan dengan model pembelajaran CLIS untuk melihat pengaruh terhadap kemampuan pemahaman konsep dan kemampuan komunikasi matematis peserta didik. Keterbaruan dalam penelitian ini adalah penggunaan alat peraga edukatif putaran turunan aljabar dalam pembelajaran CLIS untuk menilai pengaruh alat peraga terhadap kemampuan pemahaman konsep dan kemampuan komunikasi matematis. Oleh karena itu peneliti tertarik untuk melihat apakah model pembelajaran CLIS berbantuan alat peraga edukatif berpengaruh terhadap kemampuan pemahaman konsep dan kemampuan komunikasi matematis pada materi turunan fungsi aljabar.

\section{METODE}

Data yang dikumpulkan dalam penelitian ini berupa angka (kuantitas) sehingga disebut penelitian kuantitatif. Jenis eksperimen yang digunakan yaitu quasi eksperimental design. Design eksperimen yang digunakan yaitu posttest only control dengan rancangan factorial $2 \times 2$.

Tabel 1. Rencana Penelitian Eksperimental

\begin{tabular}{|c|c|c|}
\hline Model Pembelajaran (X) & $\begin{array}{l}\text { Pemahaman } \\
\text { Konsep }\left(Y_{1}\right)\end{array}$ & $\begin{array}{c}\text { Komunikasi } \\
\text { Matematis }\left(\mathrm{Y}_{2}\right)\end{array}$ \\
\hline $\begin{array}{c}\text { Model Pembelajaran CLIS } \\
\text { Berbantuan Alat Peraga Edukatif }\left(\mathrm{X}_{1}\right)\end{array}$ & $\mathrm{X}_{1} \mathrm{Y}_{1}$ & $\mathrm{X}_{1} \mathrm{Y}_{2}$ \\
\hline $\begin{array}{l}\text { Model Pembelajaran Konvensional } \\
\qquad\left(\mathrm{X}_{2}\right)\end{array}$ & $\mathrm{X}_{2} \mathrm{Y}_{1}$ & $\mathrm{X}_{2} \mathrm{Y}_{2}$ \\
\hline
\end{tabular}

Populasi dalam penelitian ini yaitu seluruh peserta didik kelas XI SMAN 1 Negerikaton. Teknik pengambilan sampel yang digunakan dalam penelitian ini yaitu teknik acak kelas. Sampel dalam penelitian ini terdiri dari 60 peserta didik yang terbagi menjadi dua kelas yaitu 30 peseta didik kelas eksperimen dan 30 peserta didik kelas kontrol. Peserta didik kelas eksperimen diberi perlakuan berupa pembelajaran CLIS berbantuan alat peraga edukatif, sedangkan kelas kontrol menggunakan model pembelajaran konvensional. Teknik analisis data dalam penelitian ini yaitu menggunakan uji One-Way Multivariate Analysis of Variants (MANOVA) dengan nilai kritis $=5 \%$. Adapun bagan alur penelitian sebagai berikut: 


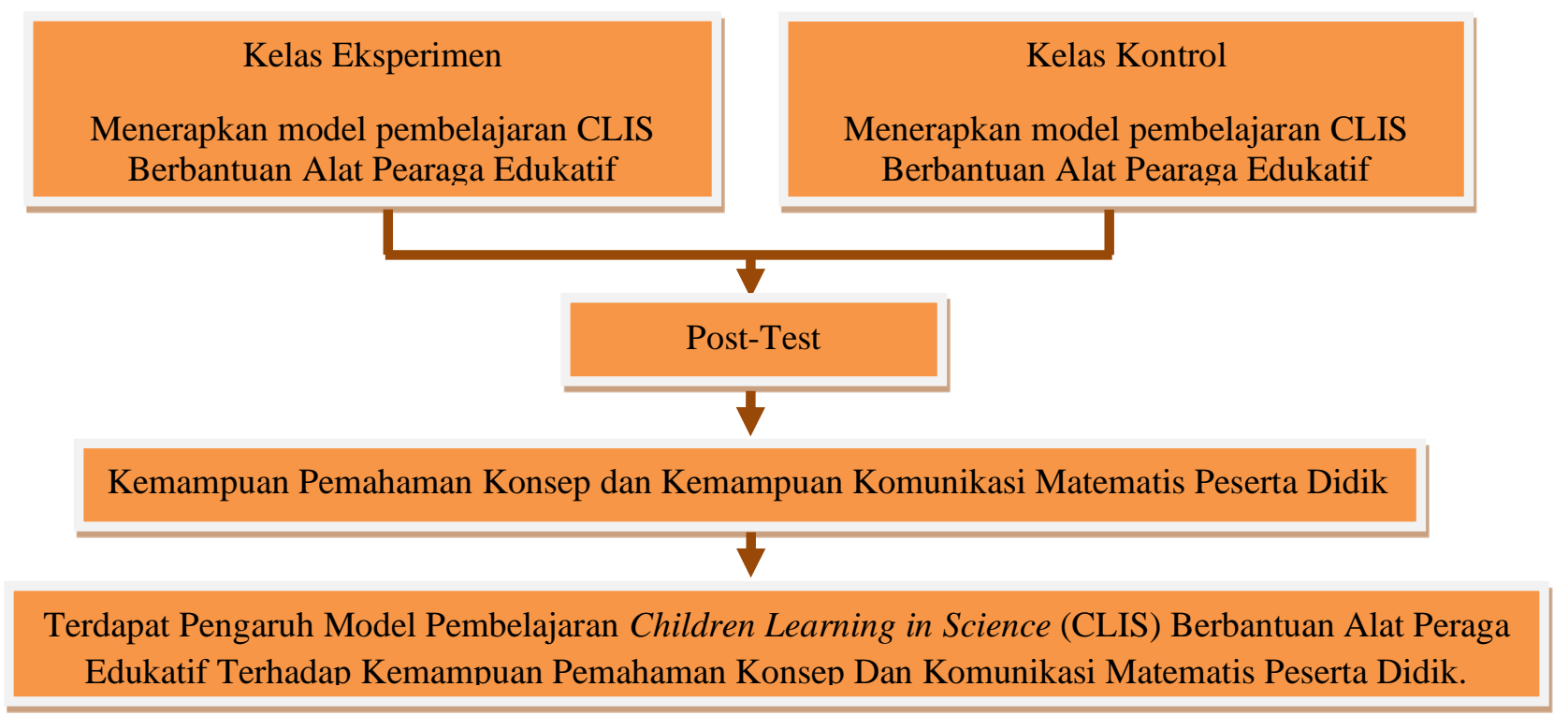

Gambar 2. Bagan Alur Pelaksanaan Penelitian

Penelitian ini terdiri dari variabel bebas (X) yaitu model pembelajaran CLIS berbantuan alat peraga edukatif, dan terdiri dari dua variabel terikat (Y) yaitu kemampuan pemahaman konsep sebagai $\left(\mathrm{Y}_{1}\right)$ dan kemampuan komunikasi matematis sebagai $\left(\mathrm{Y}_{2}\right)$. Peneliti mengambil dua kelas sebagai sampel penelitian yaitu kelas XI IPA 2 sebagai kelas eksperimen yang berjumlah 30 peserta didik dengan model pembelajaran Children Learning in Science berbantuan alat peraga edukatif dan kelas XI IPA 1 sebagai kelas kontrol yang berjumlah 30 peserta didik dengan model konvensional. Materi yang diajarkan dalam penelitian ini yaitu materi turunan fungsi aljabar. Data pengujian hipotesis dikumpulkan peneliti dengan mengajarkan materi turunan fungsi aljabar pada kelas eksperimen dan kelas kontrol yang masing-masing diadakan empat kali pertemuan, diakhir pertemuan dilaksankan post-test berupa soal uraian masingmasing 7 butir soal tes pemahaman konsep dan 6 butir soal komunikasi matematis untuk melihat kemampuan pemahaman konsep dan kemampuan komunikasi matematis peserta didik.

\section{HASIL DAN DISKUSI}

Berdasarkan hasil penelitian yang telah dilakukan didapat data nilai tes kemampuan pemahaman konsep dan kemampuan komunikasi matematis yang diberikan pada kelas eksperimen (kelas yang menerapkan model pembelajaran CLIS berbantuan alat peraga edukatif) dan kelas kontrol (kelas yang menerapkan model konvensional). Beikut adalah uraian analisis hasil pengujian.

Tabel 2. Data Deskripsi Kemampuan Pemahaman Konsep dan Kemampuan Komunikasi Matematis

\begin{tabular}{|c|c|c|c|c|c|c|c|c|c|c|}
\hline \multirow[t]{2}{*}{ Nilai } & \multirow{2}{*}{$\begin{array}{c}x \\
\max \end{array}$} & \multirow{2}{*}{$\begin{array}{c}x \\
\min \end{array}$} & \multicolumn{3}{|c|}{$\begin{array}{c}\text { Kemampuan } \\
\text { Pemahaman Konsep }\end{array}$} & \multirow[t]{2}{*}{$\begin{array}{c}x \\
\max \end{array}$} & \multirow[t]{2}{*}{$\begin{array}{c}x \\
\min \end{array}$} & \multicolumn{3}{|c|}{$\begin{array}{c}\text { Kemampuan Komunikas } \\
\text { Matematis }\end{array}$} \\
\hline & & & $\bar{x}$ & Std. Dev & $\mathbf{N}$ & & & $\bar{x}$ & Std. Dev & $\mathbf{N}$ \\
\hline \multicolumn{11}{|c|}{ Kelas Eksperimen } \\
\hline Post-Test & 91 & 78 & 83,37 & 3,364 & 30 & 95 & 70 & 80,00 & 7,311 & 30 \\
\hline \multicolumn{11}{|c|}{ Kelas Kontrol } \\
\hline Post-Test & 81 & 70 & 73,17 & 3,435 & 30 & 90 & 60 & 72,17 & 6,909 & 30 \\
\hline
\end{tabular}


Berdasarkan Tabel 2, kelas eksperimen memiliki nilai post-test yang lebih baik daripada kelas kontrol. Hal tersebut dapat dilihat dari skor rata-rata kemampuan pemahaman konsep $(83,34)$ dan kemampuan komunikasi matematis (80,00). Uji normalitas data dan uji homogenitas telah dilakukan sebelum melakukan uji hipotesis. Jika data yang dianalisis berdistribusi normal, maka teknik statistik parametrik dapat digunakan. Sebaliknya, jika data yang dianalisis tidak berdistribusi normal, maka teknik statistik nonparametrik dapat digunakan. Langkah awal yang dilakukan adalah menganalisis data uji normalitas menggunakan uji Kolmogorov-Smirnov. Hasil analisis uji normalitas dapat dilihat pada Tabel 3 berikut:

Tabel 3. Hasil Uji Normalitas

\begin{tabular}{|l|c|c|c|}
\hline \multicolumn{1}{|c|}{ Variabel } & $\begin{array}{c}\text { Kelas } \\
\text { Eksperimen }\end{array}$ & $\begin{array}{c}\text { Kelas } \\
\text { Kontrol }\end{array}$ & Kesimpulan \\
\hline Kemampuan Pemahaman Konsep & 0,71 & 0,105 & Berdistribusi \\
Kemampuan Komunikasi Matematis & 0,249 & 0,305 & normal \\
\hline
\end{tabular}

Berdasarkan Tabel 3, uji normalitas diperoleh nilai signifikansi. Oleh karena itu, data tes kemampuan pemahaman konsep dan kemampuan komunikasi matematis tersebut berasal dari populasi berdistribusi normal. Langkah selanjutnya menganalisis apakah kedua kelompok memiliki varians yang homogen atau tidak. Uji homogenitas dilakukan dengan mengunakan uji bartlett. Hasil analisis uji homogenitas dapat dilihat pada Tabel 4 berikut:

Tabel 4. Hasil Uji Homogenitas

\begin{tabular}{|c|c|c|}
\hline Variabel & Sig. & Kesimpulan \\
\hline Kemampuan Pemahaman Konsep & 0,788 & \multirow{2}{*}{ Homogen } \\
\hline Kemampuan Komunikasi Matematis & 0,525 & \\
\hline
\end{tabular}

Berdasarkan Tabel 4, menunjukan data kemampuan pemahaman konsep dan kemampuan komunikasi matematis bersifat homogen. Setelah dilakukan uji prasyarat, maka selanjutnya pengujian hipotesis dengan menggunakan uji parametrik yaitu One-Way Multivariate Analysis of Variants (MANOVA). Uji pertama adalah uji pengaruh antar variabel secara parsial. Hasil pengujian dapat dilihat pada Tabel 5 berikut:

Tabel 5. Hasil Uji MANOVA Parsial

\begin{tabular}{|c|c|c|c|}
\hline Kategori & Kemampuan & Sig. & Kesimpulan \\
\hline $\begin{array}{c}\text { Model CLIS berbantuan } \\
\text { alat peraga edukatif }\end{array}$ & Pemahaman Konsep & 0,000 & $\mathrm{H}_{0}$ ditolak \\
\cline { 2 - 4 } & Komunikasi Matematis & 0,000 & $\mathrm{H}_{0}$ ditolak \\
\hline
\end{tabular}

Berdasarkan Tabel 5. Nilai $p$-value kemampuan pemahaman konsep kurang dari 0,05 sehingga dapat disimpulkan bahwa ada pengaruh model pembelajaran CLIS berbantuan alat peraga edukatif terhadap kemampuan pemahaman konsep peserta didik. Nilai $p$-value kemampuan komunikasi matematis kurang dari 0,05 sehingga dapat disimpulkan bahwa ada pengaruh model pembelajaran CLIS berbantuan alat peraga edukatif terhadap kemampuan komunikasi matematis peserta 
didik. Setelah mengetahui hasil pengujian hipotesis untuk masing-masing kemampuan, selanjutnya dilakukan pengujian pengaruh anatar variabel secara simultan. Hasilnya dapat dilihat pada Tabel 6 berikut:

Tabel 6. Hasil Uji MANOVA Simultan

\begin{tabular}{|c|c|c|c|}
\hline Hipotesis MANOVA & & Sig. & Kesimpulan \\
\hline $\begin{array}{c}\text { Model CLIS berbantuan } \\
\text { alat peraga edukatif }\end{array}$ & Wilks' Lambda & 0,000 & $\mathrm{H}_{0}$ ditolak \\
\hline
\end{tabular}

Berdasarkan Tabel 6. Nilai $p$-value uji MANOVA menggunakan metode Wilks' Lambda adalah 0,000 dengan taraf signifikan 5\%. Dapat disimpulkan bahwa terdapat pengaruh model pembelajaran CLIS berbantuan alat peraga edukatif terhadap kemampuan pemahaman konsep dan kemampuan komunikasi matematis peserta didik. Hasil yang diperoleh peneliti memiliki relevansi dengan hasil penelitian sebelumnya yang dilakukan oleh Ajul (Sugandi and Benard 2018). Perbedaan utama yaitu penelitian sebelumnya hanya melihat pada kemampuan pemahaman konsep, sedangkan penelitian ini difokuskan pada kemampuan pemahaman konsep dan kemampuan komunikasi matematis. Penelitian yang dilakukan oleh Asep (Silaen, Adriana, and Rahayu 2021) menyelidiki pengaruh kemampuan pemahaman matematik dan kemampuan komunikasi matematik dengan menggunakan model pembelajaran yang berbeda.

Berdasarkan hasil penelitian, penerapan model pembelajaran CLIS berbantuan alat peraga edukatif pada kelas eksperimen mempengaruhi kemampuan pemahaman konsep dan kemampuan komunikasi matematis peserta didik lebih baik dibandingkan dengan kelas kontrol yang menerapakan model pembelajaran konvensional. Kelas kontrol menggunakan model pembelajaran konvensional lebih menenkankan pada proses penyampaian materi secara lisan dari seorang pendidik kepada peserta didik, peserta didik tidak diharuskan untuk mencari materi yang akan dipelajari. Berbeda dengan model pembelajaran CLIS berbantuan alat peraga edukatif, dimana peserta didik dituntut untuk membentuk komunikasi antar peserta didik untuk mencari penjelasan materi yang akan dipelajari dan dibantu dengan alat peraga untuk mempermudah proses pembelajaran.

Model pemelajaran CLIS berbantuan alat peraga edukatif membantu peserta didik menyelesaikan masalah secara berkelompok dalam suasana yang menyenangkan. Peserta didik dapat menerima materi secara percaya diri. Model pembelajaran CLIS yang terintegrasi dengan alat peraga edukatif dapat melatih peserta didik untuk berkomunikasi antar kelompok untuk bertukar ide atau gagasan. Model pembelajaran ini juga memudahkan peserta didik untuk memahami pelajaran karena kerjasama kelompok dan suasana yang kurang menegangkan. Kelemahan model pembelajaran CLIS yaitu membutuhkan waktu yang lama untuk diterapkan.

Dalam pembelajaran matematika, pemahaman konsep merupakan aspek penting yang harus dikuasi oleh peserta didik karena merupakan dasar bagi peserta didik untuk menguasai kemampuan komunikasi matematis. Oleh karena itu, kemampuan pemahaman konsep tidak dapat dipaksakan, yang artinya pendidik harus terus membantu serta memberikan stimulasi ketika konsep matematika dan logika 
sedang disampaikan. Peserta didik tidak akan dapat menyelesaikan permasalahan matematika jika dibiarkan begitu saja. Peserta didik dikatakan memahami suatu konsep jika dapat menyatakan ulang sebuah konsep, mengklasifikasi objek menurut sifat-sifat tertentu sesuai dengan konepnya, memberikan contoh dan bukan contoh, menyajikan konsep dalam berbagi bentuk representasi matemtis, menghubungkan syarat perlu dan syarat cukup, dan mengaplikasikan konsep atau aloritma ke pemecahan masalah.

Tak hanya pemahaman, kemampuan komunikasi juga merupakan kemampuan yang perlu dimiliki oleh peserta didik, karena dengan komunikasi dapat memperjelas pemahaman pada pembelajaran matematika dan merupakan cara berbagi ide. Pentingnya kemampuan komunikasi matematis mempengaruhi proses kognitif dari pemecah masalah dan membantu untuk menemukan solusi terhadap masalah yang diberikan. Untuk itu, peserta didik perlu dilatih untuk menjelaskan pemahaman konsep matematika melalui gambar, kata, serta angka. Dengan cara ini, peserta didik bisa menjadi mahir dan mengartikulasikan dalam mengkomunikasikan ide-ide matematika.

\section{KESIMPULAN}

Berdasarkan hasil analisis dan pembahasan dapat disimpulkan bahwa model pembelajaran CLIS berbantuan alat peraga edukatif pada materi turunan fungsi aljabar berpengaruh terhadap kemampuan pemahaman konsep dan kemampuan komunikasi matematis peserta didik, baik secara parsial maupun simultan. Penerapan model pembelajaran CLIS berbantuan alat peraga edukatif lebih berpengaruh terhadap kemampuan pemahaman konsep dan kemampuan komunikasi matematis peserta didik dibandingkan dengan model pembelajaran yang biasa digunakan pendidik di sekolah tersebut, baik secara parsial maupun simultan.

\section{REFERENSI}

Aminah, Siti, Tommy Tanu Wijaya, and Devi Yuspriyati. 2018. "Analisis Kemampuan Komunikasi Matematis Siswa Kelas Viii Pada Materi Himpunan." Jurnal Cendekia: Jurnal Pendidikan Matematika 2(1): 15-22.

Andini, Dwi, Nenden Mulyani, Tommy Tanu Wijaya, and Devi Nurul Supriyati. 2018. "Meningkatkan Kemampuan Komunikasi Matematis Dan Self Confidence Siswa Menggunakan Pendekatan PBL Berbantuan Geogebra.” Jurnal Derivat: Jurnal Matematika dan Pendidikan Matematika 5(1): 8293.

Arisantiani, Ni Ketut, Made Putra, and Ni Nyoman Ganing. 2017. "Pengaruh Model Pembelajaran Children Learning in Science (CLIS) Berbantuan Media Lingkungan Terhadap Kompetensi Pengetahuan IPA.” Journal of Education Technology 1(2): 125-32.

Fahrullisa, Rifa, Fredi Ganda Putra, and Nanang Supriadi. 2018. "Pengaruh Model Pembelajaran Kooperatif Tipe Think Pair Share (TPS) Berbantuan Pendekatan Investigasi Terhadap Kemampuan Komunikasi Matematis." NUMERICAL: Jurnal Matematika dan Pendidikan 
Matematika 2(2): 145.

Irawan, Hengki. 2016. "Peningkatan Motivasi Dan Prestasi Belajar Menggunakan Alat Ukur Mekanik Melalui Peraga Alat Ukur Mekanik Siswa Kelas X Teknik Kendaraan Ringan.” VANOS Journal of Mechanical Engineering $\quad$ Education 1(2): $179-88$. http://jurnal.untirta.ac.id/index.php/vanos/article/view/1019.

Jannah, Muthiah Miftahul, Nanang Supriadi, and Fraulein Intan Suri. 2019. "Efektivitas Model Pembelajaran Visualization Auditory Kinesthetic (Vak) Terhadap Pemahaman Konsep Matematis Berdasarkan Klasifikasi Self-Efficacy." AKSIOMA: Jurnal Program Studi Pendidikan Matematika 8(1): 215-24.

Khansa, Shabrina Lini, Ikrar Pramudya, and Yemi Kuswardi. 2018. "Penerapan Model Pembelajaran Discovery Learning Dengan Strategi Arias Untuk Meningkatkan Pemahaman Konsep Dan Motivasi Belajar Pada Materi Relasi Dan Fungsi.” Jurnal Pendidikan Matematika dan Matematika II(4): 262.

Krismayoni, Putu Ayu Windha, and Ni Ketut Suarni. 2020. "Pembelajaran IPA Dengan Model Pembelajaran Children Learning in Science Meningkatkan Hasil Belajar Ditinjau Dari Minat Belajar." Jurnal Pedagogi dan Pembelajaran 3(2): 138.

Nomleni, Fransina Thresiana, and Theodora Sarlotha Nirmala Manu. 2018. "Pengembangan Media Audio Visual Dan Alat Peraga Dalam Meningkatkan Pemahaman Konsep Dan Pemecahan Masalah." Jurnal Pendidikan dan Kebudayaan 8(3): 219-30.

Putri, Linda Indiyarti, and Abdul Basir. 2020. "Papan Jam Analog: Media Edukatif Pembelajaran Matematika Madrasah Ibtidaiyah.” Edumatika: Jurnal Riset Pendidikan Matematika 3(1): 33.

Rositayani, Ni Putu Era, and Ida Bagus Gede Surya Abadi. 2019. "Pengaruh Model Pembelajaran Children's Learning In Science Berbantuan Media Audio Visual Terhadap Kompetensi Pengetahuan IPA.” Jurnal Mimbar Ilmu 24(1): 63-72.

Silaen, Irgi Anggi Vahlevi, Mustika Adriana, and Rizki Rahayu. 2021. "Pengaruh Model Pembelajaran Contextual Teaching Learning Dan Realistic Mathematics Education Terhadap Kemampuan Pemahaman Konsep Dan Kemampuan Komunikasi Matematis Di Kelas VIII SMP IT Ibnu Halim Medan Tahun Pelajaran 2020/2021.” ALACRITY : Journal Of Education 1(2): 12-20.

Sugandi, Asep Ikin, and Martin Benard. 2018. "Penerapan Pendekatan Kontekstual Terhadap Kemampuan Pemahaman Dan Komunikasi Matematis Siswa SMP.” Jurnal Analisa 4(1): 16-23. Suryani, Novi Ade, Indra Sakti, and Andik Purwanto. 2018. "Perbedaan Hasil Belajar Antara Model Pembelajaran CLIS (Children's Learning In Science) Dengan Menggunakan Media KIT IPA Di SMP Negeri 21 Kota Bengkulu.” Journal of Science Education 2(1): 113-16.

Unaenah, Een et al. 2020. "Pembelajaran Matematika Operasi Hitung Bilangan Bulat Dengan Alat Peraga." Jurnal Pendidikan dan Ilmu Sosial 22(1): 117-24.

Yulianah, Lia, Khomsatun Ni'mah, and Diar Veni Rahayu. 2020. "Analisis Kemampuan Pemahaman Konsep Matematika Siswa Berbantuan Media Schoology.” Jurnal Derivat: Jurnal Matematika 
Kemampuan Pemahaman Konsep dan Komunikasi Matematis: Pengaruh Model Pembelajaran Children Leraning In Science (CLIS) Berbantuan Alat Peraga Edukatif, Taat Herliana, Nanang Supriadi, Rany Widyastuti

dan Pendidikan Matematika 7(1): 39-45. 